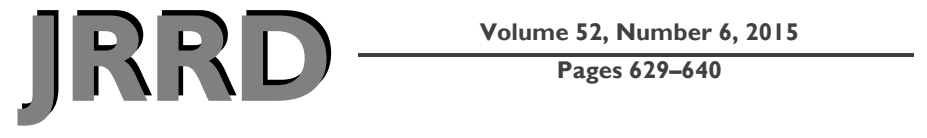

\section{Diastasis of symphysis pubis and labor: Systematic review}

\author{
M. Alicia Urraca-Gesto, PT; ${ }^{1}$ Gustavo Plaza-Manzano, PhD; ${ }^{2}$ Alejandro Ferragut-Garcías, PT; ${ }^{3}$ Daniel Pecos- $^{4}$ \\ Martín, PhD; ${ }^{4}$ Tomás Gallego-Izquierdo, PhD; ${ }^{4}$ Natalia Romero-Franco, $\mathbf{P h D}^{5^{*}}$ \\ ${ }^{1}$ Department of Rehabilitation and Physiotherapy, University Hospital Alcorcón Foundation, Madrid, Spain; \\ ${ }^{2}$ Department of Physical Medicine and Rehabilitation, Complutense University, Madrid, Spain; ${ }^{3}$ Department of Phys- \\ iotherapy and Nursery, University of Islas Baleares, Mallorca, Spain; ${ }^{4}$ Department of Physical Therapy, Alcalá Uni- \\ versity, Madrid, Spain; ${ }^{5}$ Department of Physical Therapy, Catholic University of San Antonio, Murcia, Spain
}

\begin{abstract}
Symphysis pubis diastasis (SPD) is an infrequent complication of labor that can impair womens' general health through failure of the passive stability of the pelvic girdle. Although conservative approaches are often used to decrease symptoms and interpubic separation, notably few studies have analyzed the effect of these methods on managing the symptoms of women with SPD. The purpose of this study was to review the available literature on the conservative treatment of SPD during pregnancy and labor. A computer-based search using PubMed, PEDro, and CINAHL was performed up to November 2014. We selected all studies that considered women with SPD during pregnancy or labor and treated them with conservative methods and excluded those that included surgical intervention. Eighteen studies were selected, most of which were case reports. Although the overall results of conservative treatment were unclear because of the type and design of the obtained studies, most of the studies reported bed rest in the lateral decubitus position and a pelvic girdle as basic treatments. Additionally, the few clinical trials reported recommended additional physiotherapy, including strengthening and stabilizing exercises, to reduce SPD symptoms.
\end{abstract}

Key words: conservative treatment, diastasis, exercise, interpubic gap, labor, physiotherapy, pregnancy, SPD, symphysis pubis, women's health.

\section{INTRODUCTION}

During labor, factors contributing to dilation of the birth canal might result in the total or partial breakage of the pubic symphysis, defined as a diastasis of $10 \mathrm{~mm}$ or more and associated symptomatology [1-4]. This pathology is called symphysis pubis diastasis (SPD), and epidemiological studies estimate a 2.8 percent incidence of SPD in women during and post labor [5].

SPD symptoms may appear during labor, up to $48 \mathrm{~h}$ later (when epidural analgesia disappears), or even earlier during pregnancy. Women often have pain and inflammation in the pubic symphysis, which may radiate into the lumbar and thigh areas, mainly in the medial regions. Moving, bearing a load, or raising a leg may often increase the symptoms and cause instability and incapacity while walking or standing [2-4,6-7].

The clinical approach to SPD uses conservative methods, although surgical reduction is recommended when the diastasis is greater than $4 \mathrm{~cm}$ or patients are required to bear loads quickly after delivery [7-8]. Conservative methods suggest lateral decubitus bed rest, a pelvic girdle, walking aids, and progressive mobilization

\footnotetext{
Abbreviations: $\mathrm{MeSH}=$ Medical Subject Heading, $\mathrm{SPD}=$ symphysis pubis diastasis, TENS = transcutaneous electrical nerve stimulation.

*Address all correspondence to Natalia Romero-Franco, PhD; Catholic University of San Antonio, Murcia, Los Jerónimos Campus, 135, Guadalupe, Murcia, Spain E30107; +34-968-278546; fax: +34-968-278820.

Email: narf52@gmail.com

http://dx.doi.org/10.1682/JRRD.2014.12.0302
} 
[9-10], although some clinicians also use pelvic traction [7]. Physical exercise seems to play a role in the prophylaxis of SPD [11]. Clinicians often suggest cryotherapy, transcutaneous electrical nerve stimulation (TENS), or soft massage as analgesic methods, but no studies to date have reported a clear recommendation for this pathology [9].

Despite the incapacitating nature of this pathology, up to now very few studies have investigated the success of conservative treatments for improving or even preventing this pathology. Therefore, the conservative methods to use for successfully managing SPD remain unclear, and posterior residual diastasis in women with SPD is becoming more frequent [12-13]. The purpose of this study was to systematically review the available literature on the conservative treatment of SPD during pregnancy and labor.

\section{METHODS}

The present systematic review was guided by the PRISMA statement (Preferred Reporting Items for Systematic Reviews and Meta-Analyses) [14].

The research strategy included reviewing all clinical trials, clinical cases, case series, and case studies on the treatment of SPD following childbirth. However, only case reports and case series were found in the literature. Eighteen studies were considered based on the following inclusion criteria: studies with women diagnosed with SPD, and studies regarding a conservative approach to SPD treatment following childbirth. The following exclusion criterion was applied: studies considering surgical treatment of SPD.

In the computer-based search, the following databases were included: PubMed, PEDro, and CINHAL; searches were conducted up to November of 2014. The following Medical Subject Heading (MeSH) key words were employed: pubic symphysis diastasis [MeSH], pubic symphysis separation [MeSH], pregnancy [MeSH], labor [MeSH], and pubic symphysis dysfunction [MeSH]. These terms were combined with the Boolean operator "AND."

The variables for which data were sought were pain, interpubic distance, and requirement for assistance when walking.

\section{RESULTS}

Our research strategy initially resulted in 39 manuscripts. After assessment of these manuscripts, we found 18 that met the inclusion criteria (Figure), 14 of which were case reports and 4 that were case series (Table). Therefore, the level of evidence in the majority of the selected studies was low.

All the selected articles were classified into two groups according to the intervention by which SPD was managed. The groupings were (1) studies using only bed rest, analgesics, or a pelvic girdle and (2) studies that also included physical therapy to progressively mobilize and strengthen the women in addition to walking reeducation (Table).

\section{Bed Rest, Pelvic Girdle, and Analgesics}

The majority of the studies used bed rest as the main method for managing SPD in the early phases, mainly in the lateral decubitus position. Many studies also used a pelvic girdle and/or analgesics to manage SPD as conservative treatments. Cowling and Rangan analyzed a woman with SPD (route of delivery: vaginal, single child of $3.9 \mathrm{~kg}$ ) who received bed rest and a pelvic girdle as treatment and reported a decrease of the interpubic gap from 5.4 to $4.3 \mathrm{~cm}$ after $3 \mathrm{~d}$, and a further decrease of $1.4 \mathrm{~cm}$ after $10 \mathrm{~d}$. Although the pain remained intermittent 3 mo after labor, complete resolution and elimination of pain occurred 6 mo after labor [13]. Similarly, Topuz et al. found that a woman with SPD (route of delivery: vaginal, single child of $4.8 \mathrm{~kg}$ ) who was put on bed rest and analgesics for $22 \mathrm{~d}$ after labor walked without difficulty and pain after the complete resolution of the interpubic diastasis [3]. Pedrazzini et al. reported that a woman with SPD (route of delivery: vaginal, single child of $4.0 \mathrm{~kg}$ ) who was put on bed rest, analgesics, and a pelvic girdle decreased the interpubic gap from 3.1 to $1.7 \mathrm{~cm}$ within $4 \mathrm{~d}$. The woman was discharged $16 \mathrm{~d}$ later, and she regularly wore the pelvic girdle for $40 \mathrm{~d}$. At that point, the interpubic gap was $1.1 \mathrm{~cm}$, but the woman had pain when sitting that was resolved $80 \mathrm{~d}$ after labor [22]. Chang and Markman employed bed rest, analgesics, and weight-bearing as tolerated in a woman with SPD (route of delivery: vaginal, single child of $3.0 \mathrm{~kg}$ ) and reported that the woman had gradually less pain over the next few weeks; after $6 \mathrm{mo}$, she was asymptomatic, and the interpubic gap had decreased from $5 \mathrm{~cm}$ the day after labor to $1 \mathrm{~cm}$ [23]. Similar results were obtained by Omololu et al., 


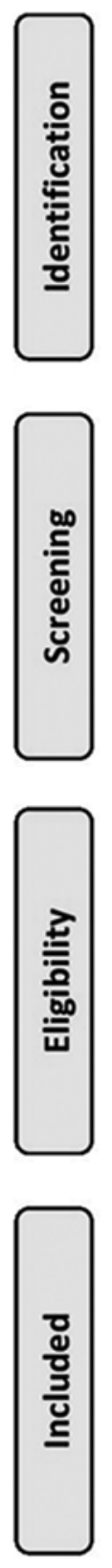

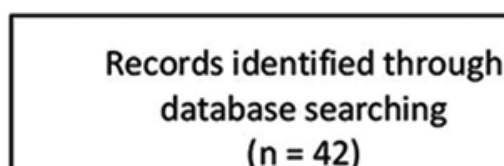

$(n=42)$
Additional records identified through other sources

$(n=25)$
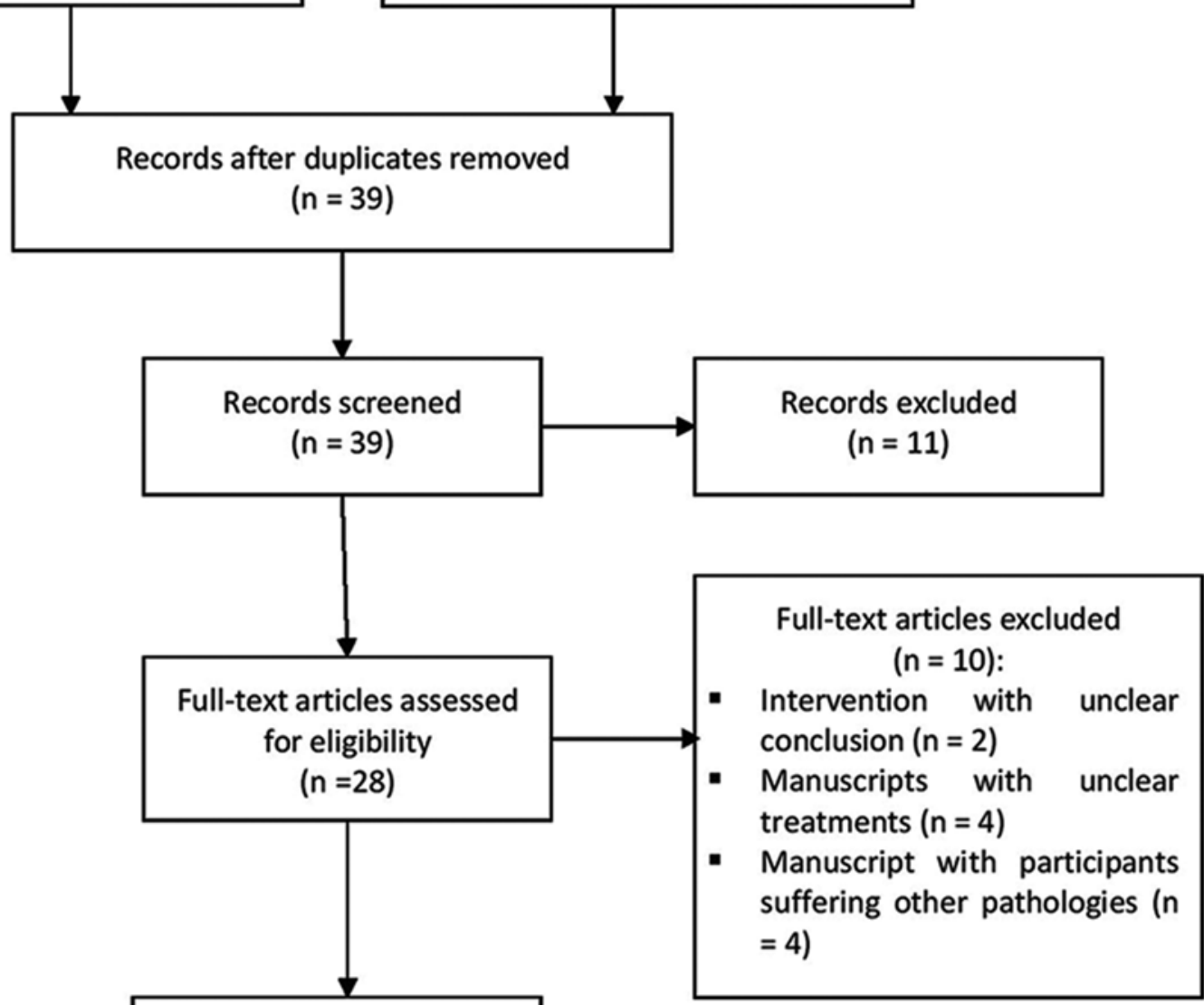

Articles included in

qualitative synthesis

( $n=18)$

Figure.

PRISMA (Preferred Reporting Items for Systemic Reviews and Meta-Analyses) flow diagram.

who employed bed rest and a pelvic girdle in a woman with SPD after labor (route of delivery: vaginal, weight of the single child not specified) and reported complete elimination of symptoms [25]. Yoo et al. reported that 9 of 11 women with SPD (route of delivery: 10 vaginal and 1 cesarean section; 7 single child and 4 twins; mean weight of babies $2.9 \pm 3.8 \mathrm{~kg}$ ) who were treated with bed rest in the lateral decubitus position, pelvic girdle, and analgesics decreased the interpubic distance by 1.5 to $2.5 \mathrm{~cm}$ on average within the 6 wk after labor, with three women still having a gap of more than $4 \mathrm{~cm}$. Two of these three women with a wide interpubic gap distance also experienced unmanageable pain and had to be surgically treated. These two women, three others who still exhibited SPD after a long follow-up, and the rest of the women showed complete resolution over 2 to $6 \mathrm{mo}$. 
JRRD, Volume 52, Number 6, 2015

Table.

Summary of manuscripts considered.

\begin{tabular}{|c|c|c|c|c|c|}
\hline Authors & Design & Intervention & $\begin{array}{c}\text { Characteristic } \\
\text { of Sample }\end{array}$ & Variables & Results \\
\hline $\begin{array}{l}\text { Yoo et al. } \\
{[15]}\end{array}$ & $\begin{array}{l}\text { Case } \\
\text { series; } \\
\text { retro- } \\
\text { spective } \\
\text { study }\end{array}$ & $\begin{array}{l}\text { Bed rest on lateral } \\
\text { decubitus, pelvic bind- } \\
\text { ers, analgesics \& pro- } \\
\text { tected weight- bearing; } \\
\text { internal fixation was } \\
\text { included in } 2 \text { women }\end{array}$ & $\begin{array}{l}N=4,151 ; \\
\text { age: } 31.5 \pm \\
7.7 \text { yr; patient } \\
\text { group }=11: \\
\text { SPD peripar- } \\
\text { tum; control } \\
\text { group }=4,140\end{array}$ & $\begin{array}{l}\text { Pain; interpubic } \\
\text { gap; follow-up for } \\
22.1 \text { mo (range: } 12 \\
\text { to } 47 \mathrm{mo} \text { ) }\end{array}$ & $\begin{array}{l}\text { Interpubic distance } \\
\text { decreased to }<1.5 \mathrm{~cm} \text { by } 2- \\
6 \text { wk after diagnosis } \& \text { then } \\
\text { remained stationary; } 5 \\
\text { women from patient group } \\
\text { had persistent symphysis } \\
\text { pubic dysfunction; pregnant } \\
\text { women with multiple gesta- } \\
\text { tions might have potential } \\
\text { risk of SPD }\end{array}$ \\
\hline Howell [17] & $\begin{array}{l}\text { Report of } \\
2 \text { cases }\end{array}$ & $\begin{array}{l}\text { Soft-tissue trigger- } \\
\text { point therapy, support } \\
\text { belt on pelvis, side- } \\
\text { lying mobilizations, } \\
\text { pelvic blocks \& instru- } \\
\text { ment-assisted pubic } \\
\text { symphysis adjust- } \\
\text { ments; home-care } \\
\text { instructions (ice, stay- } \\
\text { ing active, stretching } \\
\& \text { pain-free Kegel } \\
\text { exercises) }\end{array}$ & $\begin{array}{l}N=2 \text {; age: } 35 \\
\text { (patient } 1 \text { ) and } \\
33 \text { yr (patient } \\
\text { 2); SPD at } 30 \\
\text { wk of preg- } \\
\text { nancy }\end{array}$ & $\begin{array}{l}\text { Pain; range of lum- } \\
\text { bar motion; Faber } \\
\text { distraction test; belt } \\
\text { test; Ober's and } \\
\text { side SI compres- } \\
\text { sion; } 30 \text { wk of } \\
\text { pregnancy, right } \\
\text { after labor, } 3 \text { \& } 12 \\
\text { mo later }\end{array}$ & $\begin{array}{l}\text { Patient } 1 \text { : decrease of pain } \\
1 \text { wk after labor, with only } \\
\text { soreness } 3 \text { mo later; patient } \\
2 \text { : had symphysis pubic } \\
\text { pain } 3 \text { mo after labor; } 2 \text { mo } \\
\text { later was pain free; long- } \\
\text { term, both women reported } \\
\text { no pubic symphysis } \\
\text { symptoms }\end{array}$ \\
\hline $\begin{array}{l}\text { Shim \& Oh } \\
{[10]}\end{array}$ & $\begin{array}{l}\text { Case } \\
\text { report }\end{array}$ & $\begin{array}{l}2 \text { wk stabilization } \& \\
\text { strengthening exer- } \\
\text { cises, walking training } \\
\text { with aids \& training } \\
\text { for bed mobility; } 2 \times / d \\
\text { for } 1 \text { h each session }\end{array}$ & $\begin{array}{l}N=1 \text {; age: } \\
32 \text { yr; SPD } \\
\text { during labor }\end{array}$ & $\begin{array}{l}\text { NPRS; PSFS; } \\
\text { interpubic gap }\end{array}$ & $\begin{array}{l}\text { Decrease in NPRS from } 9.0 \\
\text { to } 4.0 \text {; decrease in PSFS } \\
\text { from } 8.0 \text { to } 3.3 ; 36 \% \\
\text { decrease in interpubic } \\
\text { distance }\end{array}$ \\
\hline $\begin{array}{l}\text { Nitsche \& } \\
\text { Howell [18] }\end{array}$ & $\begin{array}{l}\text { Case } \\
\text { report }\end{array}$ & $\begin{array}{l}\text { Bed rest \& girdle on } \\
\text { pelvis; reeducation of } \\
\text { walking }\end{array}$ & $\begin{array}{l}N=1 \text {; age: } \\
22 \mathrm{yr} \text {; SPD } \\
\text { during labor }\end{array}$ & $\begin{array}{l}\text { Walking depen- } \\
\text { dency; interpubic } \\
\text { gap; pain; right } \\
\text { after labor, } 3 \text { wk, } \\
6 \text { wk \& } 6 \text { mo later }\end{array}$ & $\begin{array}{l}\text { Interpubic gab decreased } \\
\text { from } 1.1 \text { to } 0.6 \mathrm{~cm} \& \text { pain- } \\
\text { ful walking with aids after } \\
3 \mathrm{wk} \text {; interpubic gab } \\
\text { decreased to } 0.5 \mathrm{~cm} \& \text { pain- } \\
\text { ful walking with aids after } \\
6 \mathrm{wk}\end{array}$ \\
\hline
\end{tabular}


Table. (cont)

Summary of manuscripts considered.

\begin{tabular}{|c|c|c|c|c|c|}
\hline Authors & Design & Intervention & $\begin{array}{l}\text { Characteristic } \\
\text { of Sample }\end{array}$ & Variables & Results \\
\hline $\begin{array}{l}\text { Cowling \& } \\
\text { Rangan [13] }\end{array}$ & $\begin{array}{l}\text { Case } \\
\text { report }\end{array}$ & $\begin{array}{l}\text { Bed rest \& girdle on } \\
\text { pelvis }\end{array}$ & $\begin{array}{l}N=1 \text {; age: } \\
38 \text { yr; SPD } \\
\text { during labor }\end{array}$ & $\begin{array}{l}\text { Interpubic dis- } \\
\text { tance; walking } \\
\text { dependency; pain; } \\
\text { following d after } \\
\text { labor, after } 3 \mathrm{~d} \text {, } 10 \\
\text { d, } 3 \text { mo \& } 6 \text { mo }\end{array}$ & $\begin{array}{l}\text { Decrease of interpubic gap } \\
\text { from } 5.4 \text { to } 4.3 \mathrm{~cm} \text { after } 3 \mathrm{~d} \text {; } \\
\text { decrease of interpubic gap to } \\
2.9 \mathrm{~cm} \text {, increased range of } \\
\text { movement \& increased walk- } \\
\text { ing dependency but painful } \\
\text { after } 10 \mathrm{~d} \text {; decrease of interpu- } \\
\text { bic gap to } 2.6 \mathrm{~cm} \text {, walking } \\
\text { without aids \& intermittent } \\
\text { pain after } 3 \text { mo; complete reso- } \\
\text { lution after } 6 \mathrm{mo} \text { with interpu- } \\
\text { bic gap of } 2.5 \mathrm{~cm}\end{array}$ \\
\hline Aniebue [20] & $\begin{array}{l}\text { Report of } \\
2 \text { cases }\end{array}$ & $\begin{array}{l}\text { Girdle on pelvis \& } \\
\text { physiotherapy after } 6 \mathrm{~d}\end{array}$ & $\begin{array}{l}N=2 \text {; age: not } \\
\text { specified; SPD } \\
\text { during labor }\end{array}$ & $\begin{array}{l}\text { Interpubic gap; } \\
\text { walking depen- } \\
\text { dency; pain; fol- } \\
\text { lowing d after labor } \\
\text { \& } 1 \text { mo later }\end{array}$ & $\begin{array}{l}\text { Walking independently with- } \\
\text { out pain after } 1 \text { mo }\end{array}$ \\
\hline $\begin{array}{l}\text { Topuz et al. } \\
\text { [3] }\end{array}$ & $\begin{array}{l}\text { Case } \\
\text { report }\end{array}$ & Bed rest \& analgesics & $\begin{array}{l}N=1 \text {; age: } \\
24 \mathrm{yr}\end{array}$ & $\begin{array}{l}\text { Pain; walking } \\
\text { dependency; inter- } \\
\text { pubic gap }\end{array}$ & $\begin{array}{l}\text { After } 22 \mathrm{~d} \text {, woman walked } \\
\text { without any pain or difficulty } \\
\& \text { interpubic gap was } \\
\text { assessed as normal }\end{array}$ \\
\hline $\begin{array}{l}\text { Jain \& } \\
\text { Sternberg [4] }\end{array}$ & $\begin{array}{l}\text { Case } \\
\text { report }\end{array}$ & $\begin{array}{l}\text { Girdle on pelvis, walk- } \\
\text { ing aids \& } \\
\text { physiotherapy }\end{array}$ & $\begin{array}{l}N=1 \text {; age: } \\
35 \mathrm{yr} ; \mathrm{SPD} \\
\text { during labor }\end{array}$ & Interpubic gap & $\begin{array}{l}\text { Progressive reduction of } \\
\text { interpubic gap }\end{array}$ \\
\hline $\begin{array}{l}\text { Pedrazzini et } \\
\text { al. [22] }\end{array}$ & $\begin{array}{l}\text { Case } \\
\text { report }\end{array}$ & $\begin{array}{l}40 \mathrm{~d} \text { of bed rest, analge- } \\
\text { sics \& girdle on pelvis }\end{array}$ & $\begin{array}{l}N=1 \text {; age: } \\
30 \text { yr; SPD dur- } \\
\text { ing labor }\end{array}$ & $\begin{array}{l}\text { Interpubic gap; pain; } \\
\text { d after labor, } 4 \text { d } \\
\text { later, } 12 \text { d, } 40 \text { d \& } 80 \\
\text { d later }\end{array}$ & $\begin{array}{l}\text { Decrease of interpubic gap } \\
\text { from } 3.1 \text { to } 1.7 \mathrm{~cm} \text { after } 12 \mathrm{~d} \text {, } \\
\text { to } 1.1 \mathrm{~cm} \text { after } 40 \mathrm{~d} \& \text { to } \\
1.2 \mathrm{~cm} \text { after } 80 \mathrm{~d} \text {; pain when } \\
\text { sitting after } 40 \mathrm{~d} \& \text { pain } \\
\text { release after } 80 \mathrm{~d}\end{array}$ \\
\hline
\end{tabular}


JRRD, Volume 52, Number 6, 2015

Table. (cont)

Summary of manuscripts considered.

\begin{tabular}{|c|c|c|c|c|c|}
\hline Authors & Design & Intervention & $\begin{array}{c}\text { Characteristic } \\
\text { of Sample }\end{array}$ & Variables & Results \\
\hline $\begin{array}{l}\text { Chang \& } \\
\text { Markman [23] }\end{array}$ & $\begin{array}{l}\text { Case } \\
\text { report }\end{array}$ & $\begin{array}{l}\text { Bearing weight as toler- } \\
\text { ated \& analgesics }\end{array}$ & $\begin{array}{l}N=1 \text {; age: } \\
27 \text { yr; SPD dur- } \\
\text { ing labor }\end{array}$ & $\begin{array}{l}\text { Interpubic gap; pain; } \\
\text { following d after } \\
\text { labor \& } 6 \text { mo later }\end{array}$ & $\begin{array}{l}6 \text { mo later was asymptom- } \\
\text { atic; interpubic gap } \\
\text { decreased from } 5 \text { to } 1 \mathrm{~cm}\end{array}$ \\
\hline $\begin{array}{l}\text { Culligan et al. } \\
{[1]}\end{array}$ & $\begin{array}{l}\text { Case } \\
\text { report }\end{array}$ & $\begin{array}{l}\text { Bed rest, girdle on pel- } \\
\text { vis \& physiotherapy } \\
\text { from } 14 \text { th d until } 3 \text { mo }\end{array}$ & $\begin{array}{l}N=1 \text {; age: not } \\
\text { specified; SPD } \\
\text { during labor }\end{array}$ & $\begin{array}{l}\text { Pain; walking depen- } \\
\text { dency; interpubic } \\
\text { gap; following d } \\
\text { after labor, } 6 \text { mo } \\
\text { later }\end{array}$ & $\begin{array}{l}\text { Interpubic gap progressively } \\
\text { decreased from } 5 \mathrm{~cm} \text { to nor- } \\
\text { mal measures; significant } \\
\text { pain \& walking difficulties } \\
\text { remained after } 6 \text { mo }\end{array}$ \\
\hline $\begin{array}{l}\text { Dunbar \& Ries } \\
\text { [24] }\end{array}$ & $\begin{array}{l}\text { Case } \\
\text { report }\end{array}$ & $\begin{array}{l}\text { Bed rest, reeducation of } \\
\text { walking \& infiltration } \\
\text { on pubic symphysis } \\
\text { after } 8 \mathrm{wk}\end{array}$ & $\begin{array}{l}N=1 \text {; age: } \\
33 \text { yr; SPD dur- } \\
\text { ing labor }\end{array}$ & $\begin{array}{l}\text { Pain; interpubic gap; } \\
\text { following d after } \\
\text { labor \& } 4 \text { mo later }\end{array}$ & $\begin{array}{l}\text { Was asymptomatic } 4 \text { mo } \\
\text { later }\end{array}$ \\
\hline $\begin{array}{l}\text { Snow \& } \\
\text { Neubert [7] }\end{array}$ & $\begin{array}{l}\text { Case } \\
\text { series; ret- } \\
\text { rospective } \\
\text { study }\end{array}$ & $\begin{array}{l}\text { Girdle on pelvis, phys- } \\
\text { iotherapy, TENS, anal- } \\
\text { gesics \& walking aids }\end{array}$ & $\begin{array}{l}N=9 \text {; age: not } \\
\text { specified; SPD } \\
\text { during labor }\end{array}$ & $\begin{array}{l}\text { Interpubic distance; } \\
\text { pain }\end{array}$ & Results not specified \\
\hline $\begin{array}{l}\text { Scriven et al. } \\
{[26]}\end{array}$ & $\begin{array}{l}\text { Case } \\
\text { series; } \\
\text { prospec- } \\
\text { tive study }\end{array}$ & $\begin{array}{l}\text { Bed rest \& supervised } \\
\text { mobilizations }\end{array}$ & $\begin{array}{l}N=9 \text {; age: not } \\
\text { specified; SPD } \\
\text { during labor; } \\
\text { long-term fol- } \\
\text { low-up impossi- } \\
\text { ble in } 2 \text { who } \\
\text { moved away }\end{array}$ & $\begin{array}{l}\text { Interpubic gap; pain; } \\
\text { walking depen- } \\
\text { dency; follow-up: } \\
37 \mathrm{mo} \text {, on average } \\
(2-57 \mathrm{mo})\end{array}$ & $\begin{array}{l}\text { Interpubic gap decrease of } \\
2 \mathrm{~cm}(1-3.5 \mathrm{~cm}) \text { to normal } \\
\text { measures in almost all } \\
\text { women during follow-up; } 4 \\
\text { women had pubic pain, } 2 \text { had } \\
\text { low back pain \& } 2 \text { had severe } \\
\text { incapacity at last } \\
\text { follow-up }\end{array}$ \\
\hline
\end{tabular}

NPRS = numeric pain rating scale, PSFS = Patient-Specific Functional Scale, SI = sacroiliac, SPD = symphysis pubis diastasis, TENS $=$ transcutaneous electrical nerve stimulation.

These authors also reported that the incidence of SPD in their study was 0.26 percent and that primiparity and multiple gestations were potential risks [15].

\section{Physiotherapy}

Apart from bed rest and a pelvic girdle, many studies considered physical therapy to be helpful in SPD management. Fidan et al. employed mobilization and unloading to conservatively treat a woman with SPD (route of delivery: vaginal, single child of $4.8 \mathrm{~kg}$ ) and reported a significant decrease of the interpubic gap from 5 to 3 and $1 \mathrm{~cm}$ within 2 and $3 \mathrm{~d}$, respectively, and the complete resolution of the symptoms 3 mo after labor [16]. Howell analyzed two women with SPD (route of delivery: vaginal, single babies of $4.2 \mathrm{~kg}$ and $3.7 \mathrm{~kg}$ ) who received soft-tissue trigger-point therapy and mobilization as treatment in the first days after labor and Kegel and stretching exercises as home-care instructions. Within 2 and $3 \mathrm{mo}$, both women increased their range of lumbar motion (which was restricted) and decreased their pain 
level. Twelve months later, they had pain-free symphysis pubis and a normal range of lumbar motion [17]. Shim and $\mathrm{Oh}$ analyzed a woman with SPD (route of delivery: vaginal, single child of $2.9 \mathrm{~kg}$ ) who was put on bed rest in the lateral decubitus position and a pelvic girdle the first $10 \mathrm{~d}$ after labor. Due to the lack of improvement, this woman underwent 2 wk of an exercise protocol consisting of the following three phases: stabilization and strengthening exercises: abdominal hollowing exercises, pelvic floor muscles, and hip adductor and extensor muscles exercises; training for bed mobility: rolling over and getting up and down exercises; and walking training: standing up from a chair and walking training with a walker. The authors reported that after 2 wk of these exercises, the pain significantly decreased from 9.0 to 4.0 points (on a 10-point visual analog scale), the difficulty of performing an activity decreased from 8.0 to 3.3 points, and the interpubic gap improved by 36 percent, although ascending and descending stairs remained difficult. In this study, the lack of follow-up prevented the determination of the time to complete resolution [10]. Nitsche and Howell analyzed and treated a woman with SPD (route of delivery: vaginal, single child of $4.8 \mathrm{~kg}$ ) including reeducation on walking after bed rest and showed that the interpubic gap decreased from 1.1 to $0.5 \mathrm{~cm}$ after $6 \mathrm{wk}$, but the woman continued to have pain while walking with aids [18]. Kurowski added progressive mobilization to bed rest, a pelvic girdle, and analgesics as well as a physiotherapy program that was not described in detail for a woman with SPD (route of delivery: vaginal, single child of $4.3 \mathrm{~kg}$ ) and reported that the woman was discharged with a walker 2 wk later. The lack of follow-up prevented the determination of the time to complete recovery [19]. Aniebue used physiotherapy (which was not described) after $6 \mathrm{~d}$ of bed rest and a pelvic girdle to treat two women with SPD (route of delivery: vaginal, weight of single babies not specified), who were walking independently without pain after 1 mo [20]. Joosoph and Kwek added $6 \mathrm{~d}$ of physiotherapy (which was not described) to bed rest, analgesics, and a pelvic girdle for a woman with SPD (route of delivery: vaginal, single child of $2.8 \mathrm{~kg}$ ). One week after labor, the woman was discharged. One month later, her interpubic gap of $4.5 \mathrm{~cm}$, assessed just after labor, had decreased to $2 \mathrm{~cm}$, and she was walking independently without pain 1 mo later [21]. Jain and Sternberg analyzed a woman with SPD (route of delivery: vaginal, single child of $4.4 \mathrm{~kg}$ ) whose interpubic gap separation was $9.5 \mathrm{~cm}$ just after labor. The authors found progressive reduction of the interpubic gap, painful movement, and increased functionality after physiotherapy that had not been detailed, a pelvic girdle, and bed rest. Six days after labor, the woman was discharged but continued the physiotherapy program and wearing the pelvic girdle. Six months later, the woman had a persistent interpubic gap of $5.5 \mathrm{~cm}$, pain, and difficulty walking [4]. Dunbar and Ries employed walking reeducation and administration of corticosteroids and local anesthetic to the symphysis pubis of a woman with SPD (route of delivery: vaginal; number of infants delivered not specified) after $8 \mathrm{wk}$ and showed that the woman was asymptomatic 4 mo later despite a residual diastasis of $1.3 \mathrm{~cm}$ [24]. Culligan et al. analyzed a woman with SPD (route of delivery: vaginal, single child of $3.1 \mathrm{~kg}$ ) who was in a supine position for $10 \mathrm{~d}$ after labor. A physiotherapeutic treatment $2 \times /$ wk was added on the 14th day after labor and continued for $3 \mathrm{mo}$, although the authors did not detail this physiotherapy program. The authors reported that the interpubic distance decreased, but significant pain and walking difficulty remained after $6 \mathrm{mo}$, and she needed full-time home healthcare for 3 mo. Additionally, although she returned to her normal activities $1 \mathrm{yr}$ later, she had a residual $1.3 \mathrm{~cm}$ interpubic gap after 2 yr [1]. Snow and Neubert performed a retrospective case series study of 9 women with SPD (route of delivery: vaginal, number of infants delivered not specified) who received physiotherapy and TENS, in addition to bed rest, pain control with nonsteroidal anti-inflammatory drugs, and a pelvic girdle, but the authors did not describe any specific results [7]. Scriven et al. analyzed 9 women with SPD (route of delivery: vaginal, 6 single babies and 3 twins, mean weight of babies $3.4 \pm 0.8 \mathrm{~kg}$ ) who received physiotherapy and supervised mobilization and reported a decrease in the interpubic gap from $2 \mathrm{~cm}$ on average to normal measures, but 4 women continued to have pubic pain, 2 had lower back pain, and 2 were severely incapacitated at the last follow-up, which was 37 mo later on average [26].

\section{DISCUSSION}

The present systematic review found use of physiotherapy as the main component of conservative treatment for the majority of women with SPD $[1,4,7,10,12,18$ 21,24,27-28]. Most of the studies employed physiotherapy for walking reeducation, mobilization under supervision, 
and/or strengthening the core muscles, although only two studies detailed the stabilizing and/or strengthening exercises $[10,15]$. However, the start of the physiotherapeutic treatment varied from the 2nd to the 14th day after labor [1,24-25]. Furthermore, no two women received exactly the same conservative treatment because the conservative methods differed among the studies. Despite the general recommendation for bed rest in the lateral decubitus position and use of a pelvic girdle for SPD, some women were allowed to be mobile on the 1st day after labor, depending on their symptoms $[4,7,13,20,23]$, and use of a pelvic girdle was discouraged for some women [3,23-25,27].

The lack of detailed information from many studies precludes any recommendation for the best physiotherapy program to manage SPD [1,4,7,19-21]. However, the studies that included exercise intervention reported good results in terms of pain and functionality after $2 \mathrm{wk}$ when the exercise program consisted of strengthening and stability exercises [10]. Because very few studies included exercise programs in their conservative approach, a recommendation for specific exercises as part of SPD treatment is difficult to justify. The minimal evidence to date encourages clinicians to include stabilizing and strengthening exercises during the rehabilitation of women with SPD $[6,10,17]$. The authors suggest that a strengthening (lateral pulls, standing leg-press, sitting rowing and curlup) and pelvic-stabilizing program (exercises using a ball between both knees in different positions) would strengthen deep muscles (such as the transversus abdominis and lumbar multifidus) for improved lumbar control and dynamic stability [10,17] and generate a self-brace that stabilizes the pelvis through a neuromuscular mechanism. Supporting this idea, Richardson et al. showed that a strong transversus abdominis might decrease laxity in the sacroiliac joints and the associated symptomatology [29].

A neuromuscular mechanism that reinforces the pelvic ring through strengthening exercises could explain the good results maintained over time reported in studies with follow-up of women with SPD [30]. Stuge et al. showed that lumbopelvic stability exercises produced greater improvement of pain and disability than individualized exercises in women with a pelvic girdle. These results were maintained $2 \mathrm{yr}$ later [31]. Thus, these findings suggest that the integration of pelvic-stabilizing exercises in daily tasks is the cause of these persistent improvements [30]. However, it is important to consider that not all of these women had SPD. In agreement with
Stuge et al., Shim and Oh reported that a woman with SPD who was on bed rest and wore a pelvic girdle only improved when she performed a stabilizing exercise program for $2 \mathrm{wk}$. Similar results were found by Howell, who included Kegel exercises as a strengthening program in a woman with SPD. Future studies that include the use of strengthening and stability exercises and follow-up are needed to determine the best exercise program for women with SPD.

The rest of the studies considered in the present systematic review used physiotherapy for walking reeducation and progressively mobilized patients with follow-up periods ranging from $2 \mathrm{wk}$ to $3 \mathrm{yr}[10,26]$; in addition to physiotherapy interventions, TENS, progressive mobilization, and walking supervision were employed $[7,10,17,19]$. Despite the variability in the follow-up of the studies and the conservative interventions, the evolution of SPD tended toward complete resolution of the symptoms. Any conservative method seemed to be clearly related to a quicker evolution of the SPD because several women continued to have symptoms after treatment $[8,18,27]$. Of these women, six received basic conservative treatment (bed rest in the lateral decubitus position and pelvic girdle), two of whom had to undergo an operation due to their intractable pain; three received physical therapy but the authors did not detail the programs, and four received supervised mobilization. In certain studies, we were unable to determine the time to complete recovery due to the lack of follow-up.

Studies that included strengthening and pelvicstabilizing exercises reported earlier results that were maintained over time $[10,17]$ compared with physiotherapy programs that included ergonomics [18], joint mobilization [26], electrotherapy [7], or were not specified [1,4,7,19-21].

Based on these results, most women receiving additional physiotherapy (progressive mobilization, stretching, pelvic-stabilizing, and strengthening exercises) reported complete resolution of SPD symptoms within 3 mo or earlier in most cases [16,19-21,24]. Women receiving basic conservative treatment such as a pelvic girdle and bed rest in the lateral decubitus position reported complete resolution within 6 mo in most cases $[13,15,23,25]$. Women who continued to exhibit symptoms after the follow-up in the selected studies had not performed additional stabilizing or strengthening physiotherapeutic exercises or stretching $[15,18,26]$ or the physiotherapy program was not detailed $[1,4]$. Thus, the 
addition of physiotherapy programs including progressive mobilization, stretching, strengthening, and stabilizing exercises might be recommended to manage those cases that did not respond to more limited conservative measures such as bed rest in the lateral decubitus position and pelvic girdle.

According to the results of the included studies, surgical treatment might be suggested for women whose symptoms remained after a long follow-up (more than $36 \mathrm{mo}$ ); surgical recommendation was frequently related to large pubic separation and skin rupture of the sacroiliac joint with an unstable pelvic ring. Although these women may improve, complete resolution is difficult.

Regarding the interpubic gap in women with SPD, we found a wide range of distances among the studies (from 1.1 to $9.5 \mathrm{~cm}$ ) and disappearance of symptoms despite the persistence of diastasis [1,24]. In addition, SPD symptoms often appeared immediately after labor or within the first $24 \mathrm{~h}$, when the effect of epidural analgesia had passed. Only one woman had symptoms 3 wk before labor [7]. Additionally, we found that the babies' weights varied among the women (from 2.8 to $4.8 \mathrm{~kg}$ ), in agreement with previous studies that did not find any difference in infant size between women with and without SPD [15].

In terms of potential risk factors, we found that the McRoberts maneuver was related to the SPD of four women $[1,13,18-19]$. This method is indicated for shoulder dystocia, but it is the most controversial approach during labor due to the risk of causing SPD [32]. In these four cases, the diastasis was audible to the patient and the doctor, resulting in a $4.5 \mathrm{~cm}$ interpubic gap. However, only one of the four women maintained symptoms 10 mo postpartum [18]. Additionally, a recent retrospective medical review reported that multiple gestations as well as primiparity are potential risks for SPD [15].

The primary limitation of the present systematic review is the lack of clinical trials available in the literature. Our results were based on a few clinical trials and several case reports with descriptive and retrospective designs, which are the most frequent types of investigations of SPD. SPD is a rare complication of obstetric delivery that is difficult to study using a prospective design. The heterogeneity of the conservative treatment applied to women in the various studies is another limitation. More clinical trials are needed to design detailed conservative protocols to manage SPD after labor.
Despite the limitations, this systematic review shows that, apart from bed rest in the lateral decubitus position and a pelvic girdle during the first days after labor, additional physiotherapy programs including lumbopelvic and pelvic-floor strengthening and stabilizing exercises may play a role in the management of SPD and the maintenance of improvements.

Our results showed that women with SPD tend to have complete resolution independent of the treatment, although the time to recovery might be shorter with additional physiotherapy including lumbopelvic and pelvic-floor stabilizing and strengthening exercises (deep muscles are required to gain a self-brace in the pelvic ring) $[10,17]$. Surgical treatment is only recommended in special cases with a large diastasis, persistent intractable pain, or functional requirements of the patients [15].

\section{CONCLUSIONS}

The lack of clinical trials makes determining a recommendation for a specific conservative method to manage SPD difficult. Bed rest in the lateral decubitus position and a pelvic girdle are the most extended conservative methods in SPD management. Individualized physiotherapy including progressive mobilizations and stretching as well as lumbopelvic and pelvic-floor strengthening and stabilizing exercises might help manage SPD symptoms and their maintenance over time. The majority of women tend to have complete resolution of signs and symptoms, and surgical treatment is suggested only for those women who remain symptomatic after a long follow-up.

\section{ACKNOWLEDGMENTS}

\section{Author Contributions:}

Study concept and design: M. A. Urraca-Gesto, G. Plaza-Manzano. Acquisition of data: M. A. Urraca-Gesto, A. Ferragut-Garcías, D. Pecos-Martín.

Analysis and interpretation of data: T. Gallego-Izquierdo, N. Romero-Franco.

Drafting of manuscript: M. A. Urraca-Gesto, G. Plaza-Manzano, A. Ferragut-Garcías, T. Gallego-Izquierdo.

Critical revision of manuscript for important intellectual content: D. Pecos-Martín, N. Romero-Franco.

Study supervision: M. A. Urraca-Gesto, D. Pecos-Martín, N. Romero-Franco. 
Financial Disclosures: The authors have declared that no competing interests exist.

Funding/Support: This material was unfunded at the time of manuscript preparation.

Additional Contributions: The authors would like to thank all the people who spent their time to improve this systematic review.

\section{REFERENCES}

1. Culligan P, Hill S, Heit M. Rupture of the symphysis pubis during vaginal delivery followed by two subsequent uneventful pregnancies. Obstet Gynecol. 2002;100(5 Pt 2):1114-17. [PMID:12423827] http://dx.doi.org/10.1016/S0029-7844(02)02155-5

2. Wurdinger S, Humbsch K, Reichenbach JR, Peiker G, Seewald HJ, Kaiser WA. MRI of the pelvic ring joints postpartum: Normal and pathological findings. J Magn Reson Imaging. 2002;15(3):324-29. [PMID:11891978] http://dx.doi.org/10.1002/jmri.10073

3. Topuz SC, Iyibozkurt AC, Dursun M, Akhan SE, Has R, Berkman S. Pubic symphysis diastasis: Imaging and clinical features. Eur J Radiol Extra. 2006;59:127-29. http://dx.doi.org/10.1016/j.ejrex.2006.04.021

4. Jain N, Sternberg LB. Symphyseal separation. Obstet Gynecol. 2005;105(5 Pt 2):1229-32. [PMID:15863592] http://dx.doi.org/10.1097/01.AOG.0000149744.82912.ea

5. Owens K, Pearson A, Mason G. Symphysis pubis dysfunction - a cause of significant obstetric morbidity. Eur J Obstet Gynecol Reprod Biol. 2002;105(2):143-46. [PMID:12381476] http://dx.doi.org/10.1016/S0301-2115(02)00192-6

6. Depledge J, McNair PJ, Keal-Smith C, Williams M. Management of symphysis pubis dysfunction during pregnancy using exercise and pelvic support belts. Phys Ther. 2005;85(12):1290-1300. [PMID:16305268]

7. Snow RE, Neubert AG. Peripartum pubic symphysis separation: A case series and review of the literature. Obstet Gynecol Surv. 1997;52(7):438-43. [PMID:9219278] http://dx.doi.org/10.1097/00006254-199707000-00023

8. Hou Z, Riehl JT, Smith WR, Strohecker KA, Maloney PJ. Severe postpartum disruption of the pelvic ring: Report of two cases and review of the literature. Patient Saf Surg. 2011;5(1):2. [PMID:21232102] http://dx.doi.org/10.1186/1754-9493-5-2

9. Leadbetter RE, Mawer D, Lindow SW. Symphysis pubis dysfunction: A review of the literature. J Matern Fetal Neonatal Med. 2004;16(6):349-54. [PMID:15621554] http://dx.doi.org/10.1080/jmf.16.6.349.354

10. Shim JH, Oh DW. Case report: Physiotherapy strategies for a woman with symphysis pubis diastasis occurring during labour. Physiotherapy. 2012;98(1):89-91.

\section{[PMID:22265390]}

http://dx.doi.org/10.1016/j.physio.2011.01.005

11. Aslan E, Fynes M. Symphysial pelvic dysfunction. Curr Opin Obstet Gynecol. 2007;19(2):133-39.

[PMID:17353681]

http://dx.doi.org/10.1097/GCO.0b013e328034f138

12. Hierholzer C, Ali A, Toro-Arbelaez JB, Suk M, Helfet DL. Traumatic disruption of pubis symphysis with accompanying posterior pelvic injury after natural childbirth. Am J Orthop. 2007;36(11):E167-70. [PMID:18075615]

13. Cowling PD, Rangan A. A case of postpartum pubic symphysis diastasis. Injury. 2010;41(6):657-59.

[PMID:20152970]

http://dx.doi.org/10.1016/j.injury.2010.01.112

14. Moher D, Liberati A, Tetzlaff J, Altman DG; PRISMA Group. Preferred reporting items for systematic reviews and meta-analyses: The PRISMA statement. Ann Intern Med. 2009;151(4):264-69, W64. [PMID:19622511] http://dx.doi.org/10.7326/0003-4819-151-4-200908180-00135

15. Yoo JJ, Ha YC, Lee YK, Hong JS, Kang BJ, Koo KH. Incidence and risk factors of symptomatic peripartum diastasis of pubic symphysis. J Korean Med Sci. 2014;29(2):281-86. [PMID:24550659] http://dx.doi.org/10.3346/jkms.2014.29.2.281

16. Fidan U, Ulubay M, Keskin U, Furatlıgil FB, Karaşahin KE, Ege T, Ergün A. Postpartum symphysis pubis separation. Acta Obstet Gynecol Scand. 2013;92(11):1336-37. [PMID:23855815]

http://dx.doi.org/10.1111/aogs.12216

17. Howell ER. Pregnancy-related symphysis pubis dysfunction management and postpartum rehabilitation: Two case reports. J Can Chiropr Assoc. 2012;56(2):102-11. [PMID:22675223]

18. Nitsche JF, Howell T. Peripartum pubic symphysis separation: A case report and review of the literature. Obstet Gynecol Surv. 2011;66(3):153-58. [PMID:21689485] http://dx.doi.org/10.1097/OGX.0b013e31821f84d9

19. Kurowski M. Poster 119: Conservative management of a patient with an unusually large post-partum pubic symphysis diastasis: A case report. Arch Phys Med Rehabil.

2008;89(11):E59.

http://dx.doi.org/10.1016/j.apmr.2008.09.169

20. Aniebue UU. Symphyseal diastasis following vaginal deliveries: A report of two cases. West Afr J Med. 2008; 27(1):47-49. [PMID:18689305]

21. Joosoph J, Kwek K. Symphysis pubis diastasis after normal vaginal birth: A case report. Ann Acad Med Singapore. 2007;36(1):83-85. [PMID:17285193]

22. Pedrazzini A, Bisaschi R, Borzoni R, Simonini D, Guardoli A. Post partum diastasis of the pubic symphysis: A case report. Acta Biomed. 2005;76(1):49-52. [PMID:16116827] 
23. Chang D, Markman BS. Images in clinical medicine. Spontaneous resolution of a pubic-symphysis diastasis. N Engl J Med. 2002;346(1):39. [PMID:11778001] http://dx.doi.org/10.1056/NEJMicm980471

24. Dunbar RP, Ries AM. Puerperal diastasis of the pubic symphysis. A case report. J Reprod Med. 2002;47(7):581-83. [PMID:12170537]

25. Omololu AB, Alonge TO, Salawu SA. Spontaneous pubic symphysial diastasis following vaginal delivery. Afr J Med Med Sci. 2001;30(1-2):133-35. [PMID:14510169]

26. Scriven MW, Jones DA, McKnight L. The importance of pubic pain following childbirth: A clinical and ultrasonographic study of diastasis of the pubic symphysis. J R Soc Med. 1995;88(1):28-30. [PMID:7884766]

27. Scriven MW, McKnight L, Jones DA. Diastasis of the pubic symphysis in pregnancy. BMJ. 1991;303(6793):56. [PMID:1859966] http://dx.doi.org/10.1136/bmj.303.6793.56-b

28. Dunivan GC, Hickman AM, Connolly A. Severe separation of the pubic symphysis and prompt orthopedic surgical intervention. Obstet Gynecol. 2009;114(2 Pt 2):473-75. [PMID:19622966] http://dx.doi.org/10.1097/AOG.0b013e3181998bd1

29. Richardson CA, Snijders CJ, Hides JA, Damen L, Pas MS, Storm J. The relation between the transversus abdominis muscles, sacroiliac joint mechanics, and low back pain. Spine. 2002;27(4):399-405. [PMID:11840107] http://dx.doi.org/10.1097/00007632-200202150-00015

30. Stuge B, Laerum E, Kirkesola G, Vøllestad N. The efficacy of a treatment program focusing on specific stabilizing exercises for pelvic girdle pain after pregnancy: A random- ized controlled trial. Spine (Phila Pa 1976). 2004;29(4): 351-59. [PMID:15094530] http://dx.doi.org/10.1097/01.BRS.0000090827.16926.1D

31. Stuge B, Veierød MB, Laerum E, Vøllestad N. The efficacy of a treatment program focusing on specific stabilizing exercises for pelvic girdle pain after pregnancy: A two-year follow-up of a randomized clinical trial. Spine (Phila $\mathrm{Pa}$ 1976). 2004;29(10):E197-203. [PMID:15131454] http://dx.doi.org/10.1097/00007632-200405150-00021

32. Heath T, Gherman RB. Symphyseal separation, sacroiliac joint dislocation and transient lateral femoral cutaneous neuropathy associated with McRoberts' maneuver. A case report. J Reprod Med. 1999;44(10):902-4.

[PMID:10554757]

Submitted for publication December 2, 2014. Accepted in revised form April 23, 2015.

This article and any supplementary material should be cited as follows:

Urraca-Gesto MA, Plaza-Manzano G, Ferragut-Garcías A, Pecos-Martín D, Gallego-Izquierdo T, Romero-Franco N. Diastasis of symphysis pubis and labor: Systematic review. J Rehabil Res Dev. 2015;52(6):629-40. http://dx.doi.org/10.1682/JRRD.2014.12.0302

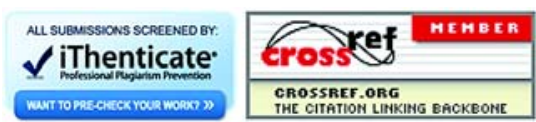


